\title{
The evaluation of a tailored intervention to improve the management of suspected viral encephalitis: protocol for a cluster randomised controlled trial
}

\author{
Ruth Backman ${ }^{1 *}$, Robbie Foy ${ }^{2}$, Peter J Diggle ${ }^{3}$, Rachel Kneen ${ }^{1,4}$, Sylviane Defres ${ }^{1,5}$, Benedict Daniel Michael ${ }^{1,6}$, \\ Antonieta Medina-Lara ${ }^{7}$ and Tom Solomon ${ }^{1,6}$
}

\begin{abstract}
Background: Viral encephalitis is a devastating condition for which delayed treatment is associated with increased morbidity and mortality. Clinical audits indicate substantial scope for improved detection and treatment. Improvement strategies should ideally be tailored according to identified needs and barriers to change. The aim of the study is to evaluate the effectiveness and cost-effectiveness of a tailored intervention to improve the secondary care management of suspected encephalitis.

Methods/Design: The study is a two-arm cluster randomised controlled trial with allocation by postgraduate deanery. Participants were identified from 24 hospitals nested within 12 postgraduate deaneries in the United Kingdom (UK). We developed a multifaceted intervention package including core and flexible components with embedded behaviour change techniques selected on the basis of identified needs and barriers to change. The primary outcome will be a composite of the proportion of patients with suspected encephalitis receiving timely and appropriate diagnostic lumbar puncture within $12 \mathrm{~h}$ of hospital admission and aciclovir treatment within $6 \mathrm{~h}$. We will gather outcome data pre-intervention and up to 12 months post-intervention from patient records. Statistical analysis at the cluster level will be blind to allocation. An economic evaluation will estimate intervention cost-effectiveness from the health service perspective.
\end{abstract}

Trial registration: Controlled Trials: ISRCTN06886935.

Keywords: Encephalitis, Cluster randomised controlled trial, Guideline implementation, Protocol

\section{Background}

There is evidence that the current clinical management of serious acute neurological infections is suboptimal [1-3]. Encephalitis, inflammation of the brain tissue, is most commonly caused by herpes simplex virus in the United Kingdom (UK) [4,5]. When herpes simplex virus encephalitis is treated promptly with aciclovir, there is a significant improvement in patient outcomes [6,7]. Encephalitis affects between five and eight people per 100,000 per year [8]. Sequelae after hospital discharge

\footnotetext{
* Correspondence: r.backman@liverpool.ac.uk

'Department of Clinical Infection, Microbiology and Immunology, Institute of Infection and Global Health, University of Liverpool, Ronald Ross Building, 8 West Derby Street, Liverpool L69 7BE, United Kingdom

Full list of author information is available at the end of the article
}

can include significant morbidities such as epilepsy, memory loss, and speech and behavioural disorders $[9,10]$, which also impair patients return to work $[10]$.

Whilst herpes simplex virus encephalitis is relatively rare [5], clinical presentations including features consistent with suspected encephalitis occur relatively frequently but in different ways to other brain injuries. Encephalitis typically presents with one or more of headache, fever, new-onset seizures, altered consciousness, and behavioural disturbances [11]. This variable and non-specific presentation often results in delayed diagnosis, especially in children who may only present with fever and irritability [12]. Furthermore, delays in 
using the main diagnostic technique, lumbar puncture, may further delay treatment [13-16].

Clinical guidelines have been developed in response to these problems $[1-3,5,17]$. However, simple dissemination of clinical guidelines is often unlikely to bring about significant changes in clinical practice [18-20]. Furthermore, interventions to implement clinical guidelines should ideally be based upon a diagnosis of barriers to change, preferably focusing on those most amenable to change [21].

\section{Aims}

We developed a multifaceted intervention package including core and flexible components with embedded behaviour change techniques selected on the basis of identified needs and barriers to change (Backman, submitted). We will evaluate the effectiveness and cost-effectiveness of a tailored intervention to improve the secondary care management of suspected encephalitis.

\section{Methods}

\section{Study design}

Participating sites will be randomly allocated to intervention or control (no intervention) arms in a cluster randomised controlled trial.

\section{Participants \\ Hospitals}

This trial takes place in the context of ENCEPH UK-Understanding and Improving the Outcome of Encephalitis, an ongoing research programme assessing the epidemiology and clinical outcomes of encephalitis. In order to reduce the likelihood of any unintended co-intervention effects we sought hospitals not directly participating in other ENCEPH UK studies. Sites had to have facilities to perform lumbar punctures and neuroimaging and willing to be randomised to intervention or control arms. We aimed to recruit a range of types of hospital, providing secondary, tertiary, (specialist) and paediatric care, to broadly represent national provision and improve the generalizability of subsequent findings.

We were aware that trainee doctors, one key target intervention group, work and rotate between different hospitals within postgraduate deaneries. If we randomised hospitals to intervention and control arms within the same deanery, there would be a risk of contamination. We therefore used deaneries as the unit of randomisation to minimise contamination.

We assessed all 266 acute trusts in England, Wales and Scotland for eligibility (Figure 1 and Additional file 1 detail a full CONSORT checklist). After excluding 47 participating in other ENCEPH UK studies and 10 specialist hospitals not usually providing routine care for suspected encephalitis patients, e.g. orthopaedic hospitals, we invited
209 hospitals to participate via senior medical members of staff.

\section{Patients}

We will identify records of patients with features suggestive of suspected encephalitis using three sets of criteria adapted from previous studies [1,22].

\section{Method 1}

Mandatory

- Acute or sub-acute (<4 weeks) alteration in consciousness, cognition, personality or behaviour persisting for more than $24 \mathrm{~h}$. Personality/behaviour change includes: agitation, psychosis, somnolence, insomnia, catatonia, mood liability, altered sleep pattern and (in children) new-onset enuresis or irritability.

Plus any two of:

- Fever $\left(\geq 38^{\circ} \mathrm{C}\right)$ or prodromal illness-acute or sub-acute

- New-onset seizures

- Focal neurological signs of acute or sub-acute onset, including focal weakness, oromotor dysfunction, movement disorders (chorea, athetosis, dystonia, hemiballismus, stereotypies, orolingual dyskinesia and tics) including Parkinsonism (bradykinesia, tremor, rigidity and postural instability) and amnesia

- Pleocytosis: cerebrospinal fluid white cell count of more than four cells per microlitre

- Neuroimaging compatible with encephalitis

- Electroencephalogram (EEG) compatible with encephalitis

\section{Method 2}

There was an initial clinical suspicion of encephalitis.

\section{Method 3}

There was a clinical suspicion of encephalitis, and the patient died before investigations were completed.

\section{Intervention package}

Using theoretically informed semi-structured interviews based upon the Theoretical Domains Framework [23,24], we explored barriers and enablers to diagnosing and managing patients with suspected encephalitis, specifically performing lumbar punctures and initiating antiviral therapy within $6 \mathrm{~h}$ (Backman, submitted). We mapped identified barriers and enablers to the patient pathway. We matched behaviour change techniques targeting clinicians to the most salient barriers and enablers and embedded them within an intervention package [25]. 


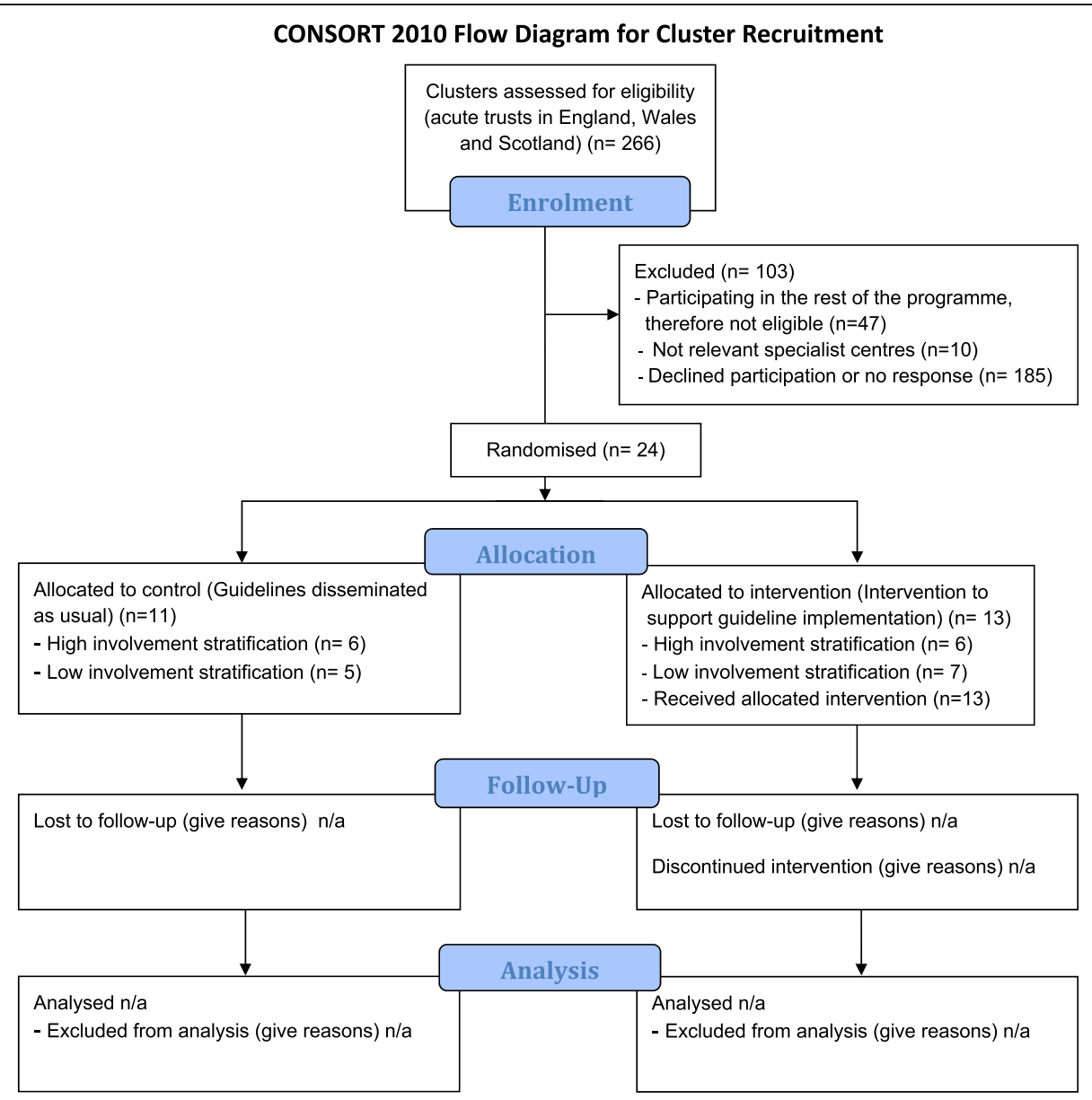

Figure 1 CONSORT 2010 checklist of information to include when reporting a cluster randomised trial.

The intervention package comprised 'core' interventions and, to allow for local flexibility, 'optional' interventions (Table 1). We defined 'core' interventions as those which we anticipated all hospitals being able to use. These included educational and action planning meetings, feedback of pre-intervention audit data and provision of lumbar puncture kits within refillable boxes. We defined 'optional' interventions which hospitals could use depending upon local resources and skills. These included decision support via phone apps and algorithms, an online quiz, prompts and posters, personalised invitation letters to attend educational meetings and a quality improvement cycle pack. Table 1 gives full details of the package following the Template for Intervention Description and Replication (TIDieR) reporting guidance [26].

We presented the package to a 1-day meeting of senior doctors and nurses from intervention hospitals. We emphasised their roles in directly delivering the various intervention components locally and recommended that they each convene an action planning meeting on return to their hospitals.

\section{Outcomes}

The primary outcome is a composite measure of the proportion of patients with suspected encephalitis whose care meets both of the following criteria: aciclovir given within $6 \mathrm{~h}$ from admission to hospital and a lumbar puncture performed within $12 \mathrm{~h}$ of hospital arrival unless clinically contraindicated.

Secondary outcomes comprise:

- The proportion of all adults started on intravenous aciclovir within an appropriate dosage range for a neurological presentation who met the definition of suspected encephalitis

- The proportion of all children started on intravenous aciclovir within an appropriate dosage range for a neurological presentation who met the definition of suspected encephalitis

- The proportion of patients with suspected encephalitis who had a lumbar puncture performed within $12 \mathrm{~h}$ unless there was a clinical contraindication 
Table 1 Intervention description using the TIDieR guidelines for intervention reporting [26]

\begin{tabular}{|c|c|c|c|c|c|c|}
\hline $\begin{array}{l}\text { Intervention } \\
\text { component }\end{array}$ & Overview of component & Materials & Who provided & $\begin{array}{l}\text { Modes and frequency of } \\
\text { delivery }\end{array}$ & $\begin{array}{l}\text { Where it will take } \\
\text { place }\end{array}$ & Tailoring \\
\hline $\begin{array}{l}\text { Training } \\
\text { day (core } \\
\text { component) }\end{array}$ & $\begin{array}{l}\text { Investigators were invited to } \\
\text { attend a training day where } \\
\text { the intervention was } \\
\text { showcased and key behaviour } \\
\text { change techniques to be } \\
\text { communicated to their } \\
\text { trainees were highlighted }\end{array}$ & $\begin{array}{l}\text { Senior clinicians were provided } \\
\text { with all the paper-based } \\
\text { intervention materials in a } \\
\text { bound form for reference. } \\
\text { Materials were also provided } \\
\text { in an electronic form for all } \\
\text { study team members }\end{array}$ & $\begin{array}{l}\text { Key behaviour changes } \\
\text { and materials were } \\
\text { delivered by the study } \\
\text { team and a representative } \\
\text { from The Encephalitis } \\
\text { Society also shared their } \\
\text { patient journey }\end{array}$ & $\begin{array}{l}\text { Delivered once per site at } \\
\text { the start of the intervention }\end{array}$ & $\begin{array}{l}\text { Took place in a central } \\
\text { location with additional } \\
\text { local meetings as } \\
\text { required }\end{array}$ & $\begin{array}{l}\text { Feedback from this session } \\
\text { led to the modification of } \\
\text { intervention materials to } \\
\text { make them more applicable } \\
\text { to each hospital }\end{array}$ \\
\hline $\begin{array}{l}\text { Action } \\
\text { planning } \\
\text { meeting (core } \\
\text { component) }\end{array}$ & $\begin{array}{l}\text { Following training, } \\
\text { investigators were asked to } \\
\text { plan an implementation of } \\
\text { intervention components }\end{array}$ & $\begin{array}{l}\text { A form was provided which } \\
\text { provided key topics to } \\
\text { discuss and plan around }\end{array}$ & $\begin{array}{l}\text { Each local PI ran the } \\
\text { meeting }\end{array}$ & $\begin{array}{l}\text { Training preceded this } \\
\text { meeting, and it was } \\
\text { requested that at least } \\
\text { one was held prior to } \\
\text { any educational sessions }\end{array}$ & $\begin{array}{l}\text { Within each hospital } \\
\text { with core team } \\
\text { members }\end{array}$ & $\begin{array}{l}\text { Sites could meet as frequently } \\
\text { as required }\end{array}$ \\
\hline $\begin{array}{l}\text { Audit and } \\
\text { feedback } \\
\text { newsletter (core } \\
\text { component) }\end{array}$ & $\begin{array}{l}\text { An audit and feedback } \\
\text { newsletter was produced } \\
\text { with personalised data } \\
\text { alongside an action } \\
\text { planning element }\end{array}$ & $\begin{array}{l}\text { Electronic and laminated } \\
\text { copies were provided which } \\
\text { contained personalised audit } \\
\text { data, a link to the guidelines } \\
\text { to promote action planning, } \\
\text { and space to add local clinical } \\
\text { leaders to add credibility }\end{array}$ & $\begin{array}{l}\text { The study team } \\
\text { provided the materials } \\
\text { with the local clinical } \\
\text { leaders distributing to } \\
\text { their team }\end{array}$ & $\begin{array}{l}\text { This was delivered } \\
\text { electronically and in hard } \\
\text { copy for distribution and } \\
\text { display alongside all other } \\
\text { intervention components }\end{array}$ & $\begin{array}{l}\text { This will be displayed } \\
\text { within the hospital } \\
\text { nearby the other } \\
\text { components such } \\
\text { as the poster or the } \\
\text { guideline algorithm }\end{array}$ & $\begin{array}{l}\text { This newsletter was personalised } \\
\text { to contain audit data from each } \\
\text { hospital. It also contained a } \\
\text { comparison with other } \\
\text { anonymised hospitals, as well } \\
\text { as to the recommended time } \\
\text { frames for care }\end{array}$ \\
\hline \multirow[t]{2}{*}{$\begin{array}{l}\text { Lumbar } \\
\text { puncture } \\
\text { box (core } \\
\text { component) }\end{array}$} & $\begin{array}{l}\text { A refillable box with all } \\
\text { the key equipment to perform } \\
\text { a lumbar puncture was } \\
\text { provided with sample } \\
\text { collection information } \\
\text { which could be locally } \\
\text { modified as required }\end{array}$ & $\begin{array}{l}\text { A box containing equipment } \\
\text { for the procedure alongside a } \\
\text { sheet detailing sample } \\
\text { collection was provided. Adult } \\
\text { and paediatric boxes were } \\
\text { available due to different } \\
\text { sample collection requirements }\end{array}$ & $\begin{array}{l}\text { The study team } \\
\text { supplied } 2-6 \text { boxes } \\
\text { to each hospital as } \\
\text { required }\end{array}$ & $\begin{array}{l}\text { Boxes were delivered at the } \\
\text { start of the intervention } \\
\text { period and on an ad hoc } \\
\text { basis }\end{array}$ & $\begin{array}{l}\text { Boxes were placed in } \\
\text { relevant locations as } \\
\text { designated by each } \\
\text { hospital }\end{array}$ & $\begin{array}{l}\text { The sample sheet could be } \\
\text { locally modified by each site to } \\
\text { accommodate sample } \\
\text { procedures }\end{array}$ \\
\hline & $\begin{array}{l}\text { Pre-made lectures with } \\
\text { integrated behaviour change } \\
\text { techniques were produced for } \\
\text { the following uses: - A session } \\
\text { focused upon the diagnostic } \\
\text { lumbar puncture - A session } \\
\text { focused upon the management } \\
\text { of suspected encephalitis - A } \\
\text { session for nurses on how to } \\
\text { help with lumbar punctures }\end{array}$ & $\begin{array}{l}\text { Pre-made lectures were } \\
\text { provided alongside a range } \\
\text { of other multimedia resources } \\
\text { including: - A DVD showing } \\
\text { nurses how to assist with the } \\
\text { procedure - Two clinical } \\
\text { vignettes - The Encephalitis } \\
\text { Society YouTube channel - } \\
\text { TS' 'Big Brain' event on } \\
\text { YouTube }\end{array}$ & $\begin{array}{l}\text { The study team } \\
\text { provided the resources } \\
\text { for the local team to } \\
\text { deliver as required }\end{array}$ & $\begin{array}{l}\text { Sites were able to choose } \\
\text { the frequency of delivery, } \\
\text { with a recommended } \\
\text { minimum of one per } \\
6 \text { months }\end{array}$ & $\begin{array}{l}\text { All training will take } \\
\text { place within the } \\
\text { hospital and will be } \\
\text { delivered by clinicians }\end{array}$ & $\begin{array}{l}\text { These materials can be locally } \\
\text { modified with a core set of } \\
\text { slides so preserve behaviour } \\
\text { change integrity. Furthermore, } \\
\text { these are all modified for use } \\
\text { in both an adult and paediatric } \\
\text { setting and can be used as } \\
\text { often as required by the local } \\
\text { team }\end{array}$ \\
\hline $\begin{array}{l}\text { Educational } \\
\text { survey (optional } \\
\text { component) }\end{array}$ & $\begin{array}{l}\text { An online multiple choice } \\
\text { educational survey was } \\
\text { developed with tailored } \\
\text { questions for doctors and }\end{array}$ & $\begin{array}{l}\text { An online multiple choice } \\
\text { educational survey was } \\
\text { developed. A certificate of } \\
\text { completion was awarded }\end{array}$ & $\begin{array}{l}\text { Site Pls were able to } \\
\text { circulate this online } \\
\text { link to all junior doctors }\end{array}$ & $\begin{array}{l}\text { The trainee would only } \\
\text { complete the survey } \\
\text { once with a certificate } \\
\text { of completion }\end{array}$ & $\begin{array}{l}\text { This could take place } \\
\text { during a teaching } \\
\text { session or during } \\
\text { private study }\end{array}$ & $\begin{array}{l}\text { Two surveys were available } \\
\text { with questions tailored for } \\
\text { doctors and nursing staff }\end{array}$ \\
\hline
\end{tabular}


Table 1 Intervention description using the TIDieR guidelines for intervention reporting [26] (Continued)

\begin{tabular}{|c|c|c|c|c|c|c|}
\hline $\begin{array}{l}\text { ClickClinica } \\
\text { [27] (optional } \\
\text { component) }\end{array}$ & $\begin{array}{l}\text { An app containing all current } \\
\text { guidelines was developed. } \\
\text { This has been promoted } \\
\text { within our package both } \\
\text { within the education and also } \\
\text { within the personalised } \\
\text { invitation letter as a useful tool }\end{array}$ & $\begin{array}{l}\text { An app has been developed } \\
\text { for use with iPhones whereby } \\
\text { all guidelines are available in } \\
\text { one place }\end{array}$ & $\begin{array}{l}\text { This app was promoted } \\
\text { through local clinical } \\
\text { leaders }\end{array}$ & $\begin{array}{l}\text { The link to download the } \\
\text { app was within the } \\
\text { educational sessions and } \\
\text { contained within the } \\
\text { direct mail letter }\end{array}$ & $\begin{array}{l}\text { Guidelines can be } \\
\text { checked and } \\
\text { downloaded on the } \\
\text { ward or within private } \\
\text { study }\end{array}$ & $\begin{array}{l}\text { None available for this } \\
\text { component }\end{array}$ \\
\hline \multirow[t]{2}{*}{$\begin{array}{l}\text { Encephalitis } \\
\text { Society leaflets } \\
\text { and video } \\
\text { (optional } \\
\text { component) }\end{array}$} & $\begin{array}{l}\text { The Encephalitis Society } \\
\text { YouTube channel was } \\
\text { included as a resource which } \\
\text { could be incorporated into the } \\
\text { education. Furthermore, } \\
\text { patient leaflets will be } \\
\text { disseminated to the } \\
\text { investigators during the study }\end{array}$ & $\begin{array}{l}\text { Printed materials for the } \\
\text { patients and healthcare } \\
\text { professionals were provided. } \\
\text { These materials were also } \\
\text { featured within the } \\
\text { educational sessions }\end{array}$ & $\begin{array}{l}\text { These were provided by } \\
\text { The Encephalitis Society, } \\
\text { forwarded by the study } \\
\text { team and disseminated } \\
\text { by the local clinical } \\
\text { leaders }\end{array}$ & $\begin{array}{l}\text { These were provided at the } \\
\text { start and middle of the } \\
\text { intervention period with } \\
\text { reinforcement from the } \\
\text { educational sessions }\end{array}$ & $\begin{array}{l}\text { The YouTube videos } \\
\text { could be used during } \\
\text { the educational session } \\
\text { or within a private } \\
\text { study session as part of } \\
\text { a critical reflection }\end{array}$ & $\begin{array}{l}\text { None available for this } \\
\text { component }\end{array}$ \\
\hline & $\begin{array}{l}\text { A quality improvement cycle } \\
\text { (plan, do, study, act (PDSA)) } \\
\text { was developed and included: - } \\
\text { A summary page with the key } \\
\text { guideline recommendations - } \\
\text { A short list of key check box } \\
\text { items to monitor current } \\
\text { practice - An excel sheet } \\
\text { which pre-plots the progress }\end{array}$ & $\begin{array}{l}\text { Printed packs were provided } \\
\text { alongside an electronic excel } \\
\text { sheet with pre-plotting graphs } \\
\text { to enable feedback }\end{array}$ & $\begin{array}{l}\text { The study team provided } \\
\text { all materials and these } \\
\text { were locally disseminated } \\
\text { by the clinical leader }\end{array}$ & $\begin{array}{l}\text { Electronic materials were } \\
\text { provided at the start of the } \\
\text { study with printed materials } \\
\text { provided within the 6-month } \\
\text { update. Local clinical leaders } \\
\text { were encouraged to ask a } \\
\text { junior doctor to assess current } \\
\text { management and feedback } \\
\text { performance data }\end{array}$ & $\begin{array}{l}\text { Within the ward where } \\
\text { the local PI is based as } \\
\text { part of a post-take } \\
\text { ward round. The qual- } \\
\text { ity improvement } \\
\text { graphs should also be } \\
\text { displayed within this } \\
\text { area }\end{array}$ & $\begin{array}{l}\text { Junior doctors are able } \\
\text { to feedback the areas of } \\
\text { compliance they feel are } \\
\text { most relevant to the } \\
\text { department }\end{array}$ \\
\hline $\begin{array}{l}\text { Basis of } \\
\text { modifiable } \\
\text { care pathway } \\
\text { (optional } \\
\text { component) }\end{array}$ & $\begin{array}{l}\text { The front sheet from the } \\
\text { quality improvement cycle } \\
\text { could also be modified to } \\
\text { form the basis of a care } \\
\text { pathway for suspected } \\
\text { encephalitis patients. This } \\
\text { will be locally driven and } \\
\text { implemented at each site }\end{array}$ & $\begin{array}{l}\text { A traffic light coloured sheet } \\
\text { with the critical patient } \\
\text { management items was } \\
\text { provided as a basis to modify }\end{array}$ & $\begin{array}{l}\text { The study team } \\
\text { provided the resource } \\
\text { and it was then } \\
\text { adapted by the local } \\
\text { clinical team }\end{array}$ & $\begin{array}{l}\text { This was provided once at } \\
\text { the start of the intervention }\end{array}$ & $\begin{array}{l}\text { Local clinical leaders } \\
\text { will modify and display } \\
\text { in key areas of the } \\
\text { hospital }\end{array}$ & $\begin{array}{l}\text { This sheet was to be locally } \\
\text { adapted if taken up }\end{array}$ \\
\hline $\begin{array}{l}\text { Algorithm } \\
\text { (optional } \\
\text { component) }\end{array}$ & $\begin{array}{l}\text { The algorithm contained } \\
\text { within the guidelines was } \\
\text { reproduced with two } \\
\text { additional features; a QR } \\
\text { code which links directly to } \\
\text { the guidelines and a box } \\
\text { that contained details for } \\
\text { local senior support }\end{array}$ & $\begin{array}{l}\text { A laminated guideline } \\
\text { algorithm was provided with a } \\
\text { QR code to link to the original } \\
\text { guidelines and a space for } \\
\text { local modification with the } \\
\text { additional of a local contact }\end{array}$ & $\begin{array}{l}\text { The study team provided } \\
\text { the materials, and they } \\
\text { were disseminated } \\
\text { throughout the hospital } \\
\text { by the local clinical team }\end{array}$ & $\begin{array}{l}\text { A minimum of five were } \\
\text { provided to each site at the } \\
\text { start and a further five were } \\
\text { also provided after } 6 \text { months }\end{array}$ & $\begin{array}{l}\text { These will be placed in } \\
\text { key areas of the } \\
\text { hospital as denoted by } \\
\text { the local clinical leader }\end{array}$ & $\begin{array}{l}\text { These are available in adult } \\
\text { and paediatric forms and can } \\
\text { be locally modified by the } \\
\text { addition of a suitable contact } \\
\text { if clinical decision support is } \\
\text { required }\end{array}$ \\
\hline $\begin{array}{l}\text { Posters } \\
\text { (optional } \\
\text { component) }\end{array}$ & $\begin{array}{l}\text { Posters with key symptoms } \\
\text { and relevant QR codes were } \\
\text { designed and graphics } \\
\text { covered paediatric, adults } \\
\text { and geriatrics }\end{array}$ & $\begin{array}{l}\text { Three posters were provided } \\
\text { to cover a variety of ages } \\
\text { alongside the key clinical } \\
\text { symptoms. A QR code to the } \\
\text { guideline was also } \\
\text { incorporated }\end{array}$ & $\begin{array}{l}\text { The study team provided } \\
\text { the materials, and they } \\
\text { were disseminated } \\
\text { throughout the hospital } \\
\text { by the local clinical team }\end{array}$ & $\begin{array}{l}\text { A minimum of five were } \\
\text { provided to each site at the } \\
\text { start, and a further five were } \\
\text { also provided after } 6 \text { months }\end{array}$ & $\begin{array}{l}\text { These will be placed in } \\
\text { key areas of the } \\
\text { hospital as denoted by } \\
\text { the local clinical leader }\end{array}$ & $\begin{array}{l}\text { None available for this } \\
\text { component }\end{array}$ \\
\hline
\end{tabular}


Table 1 Intervention description using the TIDieR guidelines for intervention reporting [26] (Continued)

\begin{tabular}{|c|c|c|c|c|c|c|}
\hline $\begin{array}{l}\text { Stickers } \\
\text { (optional } \\
\text { component) }\end{array}$ & $\begin{array}{l}\text { Small stickers with 'Think brain } \\
\text { infection' were produced for } \\
\text { application to blood sample } \\
\text { bottles }\end{array}$ & $\begin{array}{l}\text { Think brain infection' } \\
\text { stickers were provided to } \\
\text { raise awareness during the } \\
\text { sample taking procedure }\end{array}$ & $\begin{array}{l}\text { The local study team } \\
\text { provided these on an } \\
\text { ad hoc basis and the } \\
\text { local clinical leaders } \\
\text { affixed these to sample } \\
\text { bottles as required }\end{array}$ & $\begin{array}{l}\text { These were provided on } \\
\text { an ad hoc basis with } \\
\text { supplements sent within } \\
\text { the 6-month update }\end{array}$ & $\begin{array}{l}\text { These will be added } \\
\text { to all relevant bottles } \\
\text { as denoted by the } \\
\text { study team }\end{array}$ & $\begin{array}{l}\text { None available for this } \\
\text { component }\end{array}$ \\
\hline $\begin{array}{l}\text { Invitation letter } \\
\text { (optional } \\
\text { component) }\end{array}$ & $\begin{array}{l}\text { A template invitation letter } \\
\text { from the consultant inviting } \\
\text { the junior doctor to attend } \\
\text { each of the education session } \\
\text { was developed for local } \\
\text { modification. Details of the } \\
\text { lumbar puncture box and } \\
\text { ClickClinica were also included }\end{array}$ & $\begin{array}{l}\text { An electronic letter was } \\
\text { made for each of the } \\
\text { educational sessions }\end{array}$ & $\begin{array}{l}\text { The study team } \\
\text { provided the basis of a } \\
\text { letter which will then } \\
\text { be modified and sent } \\
\text { by the consultant }\end{array}$ & $\begin{array}{l}\text { This invitation letter can } \\
\text { be sent prior to all } \\
\text { educational sessions }\end{array}$ & $\begin{array}{l}\text { Letters will be sent } \\
\text { directly to the junior } \\
\text { doctors to personally } \\
\text { invite them to attend } \\
\text { the educational session }\end{array}$ & $\begin{array}{l}\text { The basis of the letter } \\
\text { was provided for local } \\
\text { modification }\end{array}$ \\
\hline
\end{tabular}


- The proportion of patients with suspected encephalitis who had a lumbar puncture at any point during the index presentation

- The proportion of patients with suspected encephalitis who had either magnetic resonance imaging (MRI) or computer tomography (CT) scan within $24 \mathrm{~h}$ of admission

- The proportion of patients with suspected encephalitis having had a lumbar puncture, who had the following cerebrospinal fluid (CSF) investigations performed: ratio of glucose within the cerebrospinal fluid and the serum calculated and having herpes simplex virus polymerase chain reaction (PCR) performed

We will also compare outcomes between adults and children.

\section{Data collection}

We recognise that suspected cases would go through one or more of several types of hospital department but mainly paediatrics, neurology, infectious diseases, medical assessment unit, accident and emergency and microbiology. Staff in participating hospitals will identify suspected cases retrospectively by performing two mandatory searches, of discharge codes for encephalitis in the preceding 12 months and of all patients undergoing a lumbar puncture within the same time period. Hospitals can also find eligible patients via records of intravenous aciclovir prescriptions or of orders for cranial CT scan or MRI within the last 12 months. We are using these combined approaches to maximise likelihood of case identification and reduce differences in ascertainment between hospitals. We included both adult and paediatric cases.

Pre-intervention, we collected data to pilot outcome measures and provide data for the feedback intervention. We aimed for 30 adult and paediatric cases per hospital to allow for possible under-recruitment in some of the smaller hospitals; however, we later sought some additional cases from higher recruiting hospitals to better inform exploratory analyses of the baseline data and to compensate for lower recruiting sites. We plan to ask for a further 30 cases per hospital in the final trial data collection, thus the total patient sample size will be a maximum of 720 . We anticipate a degree of imbalance between hospitals to achieve the total required sample size, limited by the upper limit of 40 cases per hospital.

Data are collected using structured case review forms. No patient identifiable information is sent to the central trial team. We trained data collectors, mainly nurses and trainee doctors, via face-to-face meetings and/or written briefing materials. We emphasised the need for a systematic approach to case identification to reduce the likelihood of selection bias. The trial research fellow (RB) is monitoring fidelity to the intervention via regular telephone and email contact with relevant hospitals. She is also collecting qualitative data from staff interviews and observational field notes in a sub-sample of four intervention hospitals data as part of a process evaluation.

\section{Sample size}

Using pilot data from 315 patients across 26 hospitals in four deaneries, we estimated the standard deviations of the deanery and hospital random effects to be 0.244 and 1.108 , respectively, and the current proportion of adherence to the primary outcome to be $5 \%$. Table 2 shows the power of the likelihood ratio test for a significant difference between intervention and control arms as a function of $m$, the number of eligible patients recruited per hospital, and $p$, the proportion meeting the primary outcome criteria under the intervention. Using these estimates and based upon a total of 24 hospitals, recruiting 20 patients per hospital should achieve a power of at least 0.8 when the compliance proportion under the intervention is 0.20 .

\section{Randomisation}

As explained above, we used deaneries as the unit of randomisation to minimise contamination between hospitals within the same deanery. We defined two blocks of deaneries, a block of six including hospitals (outside of the trial) where research teams were already actively involved in other ENCEPH UK studies and a block of six where there were no such ongoing studies (Figure 1). An independent statistician randomised equal numbers of clusters within each block to the intervention and routine arms, blinded to hospital identity.

\section{Statistical analysis}

We will analyse the results in $\mathrm{R}$ (www.r-project.org) using a generalised linear mixed model [28] with binomial errors, logistic link, fixed effects for blocks and treatments, random effects for deanery and for hospital. If the intervention is effective, it will raise awareness of suspected encephalitis and lead to increased documentation in the clinical records of encephalitis as a differential diagnosis. In our baseline (pre-intervention analysis),

\section{Table 2 Sample size estimates for the trial}

\begin{tabular}{llll}
\hline $\begin{array}{l}\text { Number of eligible patients } \\
\text { recruited per hospital (M) }\end{array}$ & \multicolumn{2}{l}{$\begin{array}{l}\text { Proportion meeting the primary } \\
\text { outcome criteria under the } \\
\text { intervention }(\boldsymbol{P})\end{array}$} \\
\cline { 2 - 4 } & $\mathbf{0 . 1 5}$ & $\mathbf{0 . 2 0}$ & $\mathbf{0 . 2 5}$ \\
\hline 10 & 0.487 & 0.707 & 0.845 \\
15 & 0.547 & 0.777 & 0.907 \\
20 & 0.590 & 0.809 & 0.921 \\
25 & 0.606 & 0.832 & 0.937 \\
\hline
\end{tabular}


we found that cases mainly included on this basis (method two) tended to be less likely to comply with the primary outcome criteria. One explanation is that these may represent clinical presentations at lower risk of having encephalitis and may therefore tend to be investigated and treated less thoroughly compared with more strongly suspected cases. It is therefore likely that the intervention will result in differential case mixes between the intervention and control arms, in this scenario diluting any real intervention effect. In our analysis of the outcome data, we will adjust for any relationship between the method of inclusion and compliance with the primary outcomes and analysis will be undertaken by a statistician blind to hospital assignment.

\section{Cost-effectiveness analysis}

The economic evaluation will take the perspective of the UK National Health Service (NHS). We will use trial records and observations to estimate the costs of intervention delivery. Data on health care resource utilisation will be gathered from case record reviews. Unit costs will be obtained from publicly available routine data [29,30]. Costs and health benefits occurring over 12 months will be discounted at $3.5 \%$ per annum. Therefore, results will include, in addition to incremental costs and benefits, an estimate of total cost per patient for each arm. In order to estimate quality-adjusted life years (QALYs), utility values will be estimated from the results of administering the EQ-5D, primary economic outcome, and the SF-6D utility scores derived from the SF-36, following Brazier's methodology [31].

We will analyse cost data using regression methods for handling censored cost data and accounting for clustered nature of the data [32]. We will analyse costs and benefits jointly using a bivariate probability distribution. Sample uncertainty in estimated cost difference and incremental cost-effectiveness ratios between arm groups will be described using bootstrapped confidence intervals [33] as well as with cost-effectiveness acceptability curves. Parameter uncertainty and robustness of findings will be accounted for through univariate sensitivity analysis and probabilistic sensitivity analysis.

Estimates of costs and health outcome (utilities) will be used to populate a model of suspected encephalitis patient management in both intervention and control conditions. The model will cover the remaining patient lifetime within which the (probability of) cost-effectiveness of the alternative will be analysed [34]. Data analysis will be performed using Stata [35].

\section{Ethical review}

The study was reviewed by Preston North West Research Ethics Committee (13/NW/0279) (Additional file 2).

\section{Trial status}

The trial is ongoing with pre-intervention data collection completed; we are yet to undertake post-intervention outcome data collection and analysis.

\section{Additional files}

\section{Additional file 1: CONSORT 2010 checklist of information to include} when reporting a cluster randomised trial.

Additional file 2: Confirmation of ethical approval.

\section{Competing interests}

Robbie Foy is Deputy Editor-in-Chief of Implementation Science. All decisions about this manuscript were made by another editor.

\section{Authors' contributions}

RB wrote the first draft of the protocol and all authors participated in further drafting. PD planned and performed all statistical work and AML planned the health economics. TS and RF conceived the original idea for this study.

All authors read and approved the final manuscript.

\section{Acknowledgements}

This paper summarises the independent research funded by the National Institute for Health Research under its Programme Grants for Applied Research scheme ("Understanding and Improving the Outcomes of Viral Encephalitis"; RP-PG-0108-10048). The views expressed are those of the authors and not necessarily those of the NHS, the NIHR or the Department of Health.

\section{Funding}

UK National Institute for Health Research (NIHR) Programme for Applied Research: "Understanding and Improving the Outcomes of Viral Encephalitis"; RP-PG-0108-10048.

\section{Author details}

1Department of Clinical Infection, Microbiology and Immunology, Institute of Infection and Global Health, University of Liverpool, Ronald Ross Building, 8 West Derby Street, Liverpool L69 7BE, United Kingdom. ${ }^{2}$ Leeds Institute of Health Sciences, University of Leeds, Charles Thackrah Building, 101 Clarendon Road, Leeds LS2 9LJ, United Kingdom. ${ }^{3}$ Department Epidemiology and Population Health, Institute of Infection and Global Health, University of Liverpool, Ronald Ross Building, 8 West Derby Street, Liverpool L69 7BE, United Kingdom. ${ }^{4}$ Department of Neurology, Alder Hey Children's NHS Foundation Trust, Eaton Road, Liverpool L12 2AP, United Kingdom. ${ }^{5}$ Royal Liverpool and Broadgreen University Hospitals Trust, Liverpool L7 8XP, United Kingdom. ${ }^{6}$ The Walton Centre NHS Foundation Trust, Lower Lane, Fazakerly, Liverpool L9 7LJ, United Kingdom. ${ }^{7}$ Health Economics Group, University of Exeter Medical School, Veysey Building, Salmon Pool Lane, Exeter EX2 4SG, United Kingdom.

Received: 17 December 2014 Accepted: 23 December 2014 Published online: 27 January 2015

\section{References}

1. Michael BD, Sidhu M, Stoeter D, Roberts M, Beeching NJ, Bonington A, et al. North West Neurological Infections Network. Acute central nervous system infections in adults - a retrospective cohort study in the NHS North West region. QJM. 2010;103(10):749-58.

2. Bell DJ, Suckling R, Rothburn MM, Blanchard T, Stoeter D, Michael BD, et al. Management of suspected herpes simplex encephalitis in adults in a U.K. teaching hospital. Clin Med. 2009;9(3):231-5.

3. Kelly C, Sohal A, Michael BD, Riordan A, Solomon T, Kneen R. Suboptimal management of central nervous system infections in children: a multicentre retrospective study. BMC Pediatr. 2012;12:145.

4. Michael BD, Solomon T. Seizures and encephalitis: clinical features, management, and potential pathophysiologic mechanisms. Epilepsia. 2012;53:63-71 
5. Solomon T, Michael BD, Smith PE, Sanderson F, Davies NWS, Hart I, et al. National Encephalitis Guidelines Developement and Stakeholders Group. Management of suspected viral encephalitis in adults-Association of British Neurologists and British Infection Association National Guidelines. J Infect. 2012;64:347-73.

6. Hughes PS, Jackson AC. Delays in initiation of acyclovir therapy in herpes simplex encephalitis. Can J Neurol Sci. 2012;39:644-8.

7. Raschilas F, Wolff M, Delatour F, Chaffaut C, De Broucker T, Chevret S, et al. Outcome of and prognostic factors for herpes simplex encephalitis in adul patients: results of a multicenter study. Clin Infect Dis. 2002;35(3):254-60.

8. Granerod J, Cousens S, Davies NWS, Crowcroft NS, Thomas SL. New estimates of incidence of encephalitis in England. Emerg Infect Dis. 2013;19(9):1455-62.

9. McGrath N, Anderson NE, Croxson MC, Powell KF. Herpes simplex encephalitis treated with aciclovir: diagnosis and long term outcome. J Neurol Neurosurg Psychiatry. 1997;63:321-6.

10. Mailles A, De Broucker T, Costanzo P, Martinez-Almoyna L, Vaillant V, Stahl J-P. Long-term outcome of patients presenting with acute infectious encephalitis of various causes in France. Clin Infect Dis. 2012;54(10):1455-64.

11. Solomon T, Hart IJ, Beeching NJ. Viral encephalitis: a clinician's guide. Pract Neurol. 2007;7:288-305

12. Kneen R, Jakka S, Mithyantha R, Riordan A, Solomon T. The management of infants and children treated with aciclovir for suspected viral encephalitis. Arch Dis Child. 2010;95:100-6.

13. Kneen $\mathrm{R}$, Solomon T, Appleton R. The role of lumbar puncture in suspected CNS infection-a disappearing skill? Arch Dis Child. 2002;87(3):181-3.

14. Hasbun R, Abrahams J, Jekel J, Quagliarello V. Computed tomography of the head before lumbar puncture in adults with suspected meningitis. $\mathrm{N}$ Engl J Med. 2001;345(24):1727-33.

15. Heyderman RS, Lambert HP, O'Sullivan I, Stuart JM, Taylor BL, Wall RA. Early management of suspected bacterial meningitis and meningococcal septicaemia in adults. J Infect. 2003:46:75-7.

16. Kneen $\mathrm{R}$, Solomon $\mathrm{T}$, Appleton $\mathrm{R}$. The role of lumbar puncture in children with suspected central nervous system infection. BMC Pediatr. 2002;2:8.

17. Kneen R, Michael BD, Menson E, Mehta B, Easton A, Hemingway C, et al. Management of suspected viral encephalitis in children-Association of British Neurologists and British Paediatric Allergy Immunology and Infection Group National guidelines. J Infect. 2012:64:449-77.

18. Thomas RH, Smith PE. Encephalitis guidelines: a recipe for success? Clin Med. 2009;9(3):210-1.

19. Cabana MD, Rand CS, Powe NR, Wu AW, Wilson MH, Abboud PAC. Why don't physicians follow clinical practice guidelines? A framework for improvement. JAMA. 1999;282:1458-65.

20. Gagliardi AR, Brouwers MC, Palda VA, Lemieux-Charles L, Grimshaw JM. How can we improve guideline use? A conceptual framework of implementability. Implement Sci. 2011;6:26.

21. Baker R, Camosso-Stefinovic J, Gillies C, Shaw EJ, Cheater F, Flottorp S, et al. Tailored interventions to overcome identified barriers to change: effects on professional practice and health care outcomes. The Cochrane Database of Systematic Reviews. 2010;3, CD005470. Doi:10.1002/14651858.CD005470. pub2.

22. Granerod J, Ambrose H, Davies N, Clewley J, Walsh A, Morgan D, et al. Causes of encephalitis and differences in their clinical presentations in England: a multicentre, population-based prospective study. Lancet Infect Dis. 2010;10(12):835-44.

23. Michie S, Johnston M, Francis J, Hardeman W, Eccles M. From theory to intervention: mapping theoretically derived behavioural determinants to behaviour change techniques. Appl Psychol. 2008;57(4):660-80.

24. Cane J, O'Connor D, Michie S. Validation of the theoretical domains framework for use in behaviour change and implementation research. Implement Sci. 2012;7:37.

25. Michie S, Richardson M, Johnston M, Abraham C, Francis J, Hardeman W et al. The behavior change technique taxonomy ( $v 1)$ of 93 hierarchically clustered techniques: building an international consensus for the reporting of behavior change interventions. Ann Behav Med. 2013;46(1):81-95.

26. Hoffmann TC, Glasziou PP, Boutron I, Milne R, Perera R, Moher D, et al. Better reporting of interventions: template for intervention description and replication (TIDieR) checklist and guide. BMJ. 2014;348:g1687.

27. Michael B, Geleta D. Development of ClickClinica: a novel smartphone application to generate real-time global disease surveillance and clinical practice data. BMC Med Inform Decis Mak. 2013;13:70.
28. Breslow NE, Clayton DG. Approximate inference in generalized linear mixed models. J Am Stat Assoc. 1993:88:9-25.

29. Health Do: Reference costs guidance 2013-14. In. Edited by Health Do; 2014.

30. Curtis L: PSSRU Unit Costs of Health \& Social Care 2013. In. University of Kent (United Kingdom); 2013.

31. Brazier J, Roberts J, Deveril M. The estimation of a preference-based measure of health from the SF-36. J Health Econ. 2002;21:271-92.

32. Grieve R, Cairns J, Thompson SG. Improving costing methods in multicentre economic evaluation: the use of multiple imputation for unit costs. Health Econ. 2010;19(8):939-54.

33. Chaudhary M, Stearns S. Estimating confidence intervals for cost effectiveness ratios: an example from a randomized trial. Stat Med. 1996;15:1447-58.

34. Fenwick E, Claxton K, Sculpher M. Representing uncertainty: the role of cost-effectiveness acceptability curves. Health Econ. 2001;10:779-87.

35. StataCorp. Stata statistical software. 9th ed. College Station, TX: StataCorp LP; 2005.

\section{Submit your next manuscript to BioMed Central and take full advantage of:}

- Convenient online submission

- Thorough peer review

- No space constraints or color figure charges

- Immediate publication on acceptance

- Inclusion in PubMed, CAS, Scopus and Google Scholar

- Research which is freely available for redistribution 